\title{
Financial Determinants of Corporate Governance Disclosure: Portuguese Evidence
}

\author{
By Vera Lúcia M. Cunha* \\ Sílvia M. Dinis Mendes ${ }^{\dagger}$
}

The present study analyses the financial determinants of the level of corporate governance disclosure (CGD) across a large sample of Portuguese firms, listed in the Euronext Lisbon index, in the period between 2005 and 2011. An index, using data drawn from firms' annual reports regarding corporate governance, was constructed based on content analysis to measure CGD levels. An ordinal logistic model was formulated to explore the financial determinants of information disclosure. The present study's main findings suggest that firm size and growth opportunities had a significant and positive influence on CGD while financial leverage negatively affected the latter. Finally, no relationship was observed between CGD and financial performance.

Keywords: Financial Determinants, Disclosure index, consolidated annual reports, Portugal.

\section{Introduction}

An organised and detailed reporting system enables investors to understand, and obtain precise and consistent information about companies and consequently make better investment decisions (Ho et al. 2008). According to Healy and Palepu (2001), financial reporting and corporate disclosure are considered essential means for companies to let know corporate governance structures and performance to external investors, and by this way reducing agency costs. Disclosure can be defined "as transferring and presenting economic information associated with the financial status and performance of firms, whether financial or nonfinancial, quantitative or in other forms" (Ghasempour and MdYusof 2014: 1).

However, the disclosure strategy of a company depends on the analysis of costs and benefits that managers believe to be associated with the disclosure of information (Gibbins et al. 1990). Information disclosure can benefit companies in many ways, for example increasing the liquidity of shares in the market (Healy et al. 1999), reducing the cost of capital by reducing transaction costs and increasing the demand for stocks (Lev 1992, Botosan and Plumlee 2002, Lawrence and Stapledon 1999), or improving the company's stock price (Lang and Lundholm 2000).

In sum, the benefits of corporate disclosure arise mainly from information asymmetry reduction between informed and uninformed investors (Diamond

\footnotetext{
* Polytechnic Institute of Coimbra, Portugal.

${ }^{\dagger}$ Assistant Professor, Polytechnic Institute of Coimbra, Portugal.
} 
and Verrecchia 1991) and decreasing costs to obtaining information from investors (Kim and Verrecchia 1994). Given the increasing number of investors, this leads to reduced costs of capital for companies, an increased interest by financial analysts and increasing liquidity of stocks (Healy et al. 1999). The benefits of disclosure also include the reduction of the effective debt interest rate (Sengupta 1998).

Companies, however, can hold costs when information is disclosed. Litan and Wallison (2000) admit that disclosing information may bring competitive disadvantages for companies. However, most of the information - financial or non-financial - does not carry this risk, because managers can hide information that may contribute to the loss of competitiveness and estimate these consequences. Property costs are particularly relevant regarding the decision to disclose or not additional information (Verrecchia 1983). Verrecchia (1983) argues that companies have no incentives to disclose information that will reduce their competitive position, even if it makes it more costly to raise additional capital. However, property costs are sensitive to the competitive nature of the market, the type of private information disclosed and the threat of entry of new firms into the market (Darrough and Stoughton 1990).

Studies about the disclosure have been conducted in many developed countries. In order to protect the interest of different investors and third parties of the market, a legal and efficient system of disclosure is needed. In Portugal, the first corporate governance set of recommendations was produced by the Portuguese Securities Market Commission (also known by CMVM) in 1999, seeking to transpose to the national context the reflection of the corporate governance of listed companies. From this date the CMVM recommendations on corporate governance have been constantly evolving with regard to its content and its regulatory environment. With the recent publication of Regulation $\mathrm{N}^{\circ} 4 / 2013$ of 18 July of 2013 , are now more than fifty the CMVM recommendations with direct impact on corporate governance of listed companies.

Research on corporate disclosure determinants began with the work of Cerf (1961), who examined the importance of different voluntary disclosure media for financial analysts, and has been a continuous topic of investigation. Further studies have analysed the impact of firm's characteristics, financial and non-financial variables on corporate disclosure. Smith and Watts (1992), Gaver and Gaver (1993), Hossain et al. (2005), Eng and Mak (2003) and more recently Huafang and Jianguo (2007), Ghasempour and MdYusof (2014) and Scholtz and Smit (2015), analyse financial leverage, growth opportunities, firm size and performance as determining factors in the context of information asymmetry, agency theory and stakeholder theory.

In order to understand the determining factors that influence the level of CGD, we examine a large sample of Portuguese listed firms on Euronext Lisbon over the period 2005 to 2011. Our results show that firm size and growth opportunities had a significant and positive influence on the level of CGD, whereas financial leverage had a significant and negative influence on 
CGD. No relationship was observed between the level of CGD and financial performance.

This paper is organized as follows. Section 2 introduces relevant literature and the research hypotheses. Section 3 describes our data and research methodology, while section 4 presents and discuss the main results. Finally, the section 5 concludes the paper.

\section{Literature Review and Investigation Hypotheses}

\section{Financial Leverage}

Jensen and Meckling (1976) suggests that conflicts of interest between shareholders and creditors arise when a firm uses debt capital. Increases in debt to reduce agency costs of equity, or for any other reason, can lead the firm to face another type of cost: the agency costs associated with debt capital. Thus, creditors create restrictions on firm's access to credit because shareholders can invest in high-risk projects, searching to increase the value of the equity rather than the expense of the debt. Therefore, increasing financial leverage is one of the possible ways of reducing the agency costs associated with equity.

Stakeholder's theory can also explain the effect of leverage on the level of disclosure. The common assumption that highly indebted companies have a greater number of creditors justifies that companies disclose more information to these stakeholders, thus firms have the obligation to render or publish accounts. In Portugal, banks (the main creditors of the firms) do not encourage firms with higher debt levels to disclosure the information on annual reports, since they use informal mechanisms to obtain this information (Oliveira et al. 2013). Ben-Amar and Boujenoui (2007) states that highly leverage firms should increase their disclosure level to reduce agency costs associated to debt. These firms should improve disclosures levels to restore the confidence of their investors and creditors and thus reduce the perception of bankruptcy risk.

In general, the results of empirical studies that relate leverage and information disclosure indicate opposite signs. Some authors find a positive relationship (Aljifri and Hussaney 2007, Kateb 2012, Juhmani 2013, Jouirou and Chenguel 2014), while others do not observe any relationship (Hannifa and Cooke 2002, Lopes and Rodrigues 2007, Allegrini and Greco 2013, Ghasempour and MdYusof 2014) and some even showed a negative relationship (Eng and Mak 2003, Barros et al. 2013, Oliveira et al. 2013).

Therefore, we formulated the following research hypothesis:

H1: There is a relationship between leverage and CGD.

\section{Growth Opportunities}

It is argued that the existence of investment opportunities is associated with information asymmetry, as well as the existence of high agency costs 
(Smith and Watts 1992, Gaver and Gaver 1993). Ben-Amar and Boujenoui (2007) suggest that firms with higher growth opportunities must be associated to higher CGD levels, enabling to reduce information asymmetry to external investors. The managers increase the levels of disclosure, including compensation disclosure, in order to reduce the existence of asymmetric information between managers and investors.

The measurement of investment opportunities in financial reality of CGD becomes more complicated and even ambiguous. Adam and Goyal (2008), suggest that market-to-book assets ratio is the best proxy to measure business investment opportunities because it contains more information about this matter when compared to other ratios as market-to-book equity or earningsprice. According to the authors, market-to-book assets ratio may also be defined as Tobin Q because, according to Perfect and Wiles (1994), the two ratios correlation is about 96\%. Neverthless, Lang, Ofek and Stulz (1994) and Yermack (1996), among others, used Tobin's Q as a proxy.

Hutchinson and Gul (2004) suggest that firms with higher growth opportunities are more difficult to monitor. Therefore, corporate governance mechanisms play an important role in the management of these firms.

Huafang and Jianguo (2007), James (2011) and Ghasempour and MdYusof (2014) found that firms with high growth opportunities are more reluctant to voluntary disclosure. James (2011) suggests that high growth firms may require a higher proportion of executive directors to take advantage of their opportunities, influencing the monitoring ability of the board and affecting negatively corporate governance recommendations compliance.

A positive relationship between growth opportunities and disclosure was reported by Hossain et al. (2005) and Alves et al. (2012). However, Eng and Mak (2003) and Scholtz and Smit (2015) found no significant relationship between disclosure information and the growth of firms.

Therefore, we formulated the following hypothesis:

$\mathrm{H} 2$ : There is a positive relationship between growth opportunities and the level of CGD.

\section{Firm Size}

Agency theory also explains the relationship between the disclosure and the size of the firm. Schiantarelli (2005) indicates that firm size is inversely correlated with the concentration of capital, since ownership concentration arises as a mechanism that can mitigate agency problems between managers and outside investors. This consideration seems more relevant for large and listed firms. Silva and Carreira (2010) also suggest that asymmetric information problems become more severe for younger and smaller firms, since the lack of information available in the market leads to lending operations with higher risk assessments. Thus, younger and smaller firms are expected to suffer from major constraints in access to credit (Peterson and Rajan, 1994). 
Accounting practice and voluntary disclosure should control conflicts of interest between shareholders, creditors and investors (Leftwich et al. 1981). It is argued that agency costs increase with the level of foreign capital, which in turn, increases with firm size. Large firms face higher political costs associated with high visibility and government intervention. To reduce these costs, they use greater disclosure levels because they do not consider the latter as an important threat to their competitive advantage (Healy and Palepu 2001). The costs of information disclosure also explain the positive association between disclosure levels and the firm size (Raffournier 1995). Finally, a significant and positive relationship between firm size and disclosure is reported by Craven and Martson (1999), Eng and Mak (2003), Gul and Leung (2004), Marston and Polei (2004), Arcay and Vazquez (2005), Ben-Amar and Zeghal (2011), Mallin and Ow-Yong, (2012), and Barros et al. (2013).Therefore, we formulated the following hypothesis:

H3: There is a positive relationship between firm size and the level of CGD.

\section{Firm Performance}

Firms' performance has been extensively studied, but research findings regarding the relationship between financial performance and disclosure are not unanimous. Ben-Amar and Boujenoui (2007) argue that not only firms with high financial performance disclose more information to the market, but also firms with poor performance have large incentives to disclose information, searching to attract investment and thus, improve their financial ratios. Jouirou and Chenguel (2014) argue that firms with higher profit levels are more likely to disclose higher levels of information, to inform the market about their performance thus, reducing information asymmetry, increasing investor confidence and finally, obtaining adequate compensation for their managers.

Marston and Polei (2004) and Chavent et al. (2006) show a significant and positive relationship between returns to assets and disclosure. Other studies show that a negative relationship exists (Camfferman 2002, Bujaki and McConomy 2002) while Barako et al. (2006), Ghasempour and MdYusof (2014), Jouirou and Chenguel (2014), and Scholtz and Smit (2015) find no substantive correlation.

Based on the above review of the literature, we formulate the following hypothesis:

H4: There is a positive relationship between company performance and the level of CGD. 


\section{Research Design}

Sample

Our study's population consists of all non-financial Portuguese companies listed on Euronext Lisbon, from 2005 to 2011. We eliminated from the panel all firms operating in the financial sector and the all the anonymous sports societies. Our final sample comprises a total of 263 observations. The choice of this period is motivated by the availability of corporate governance and annual reports during the collection period.

\section{Regression Model}

To examine the relationship between the level of CGD and its determinants we use the following ordinal logistic regression model:

$$
\mathrm{CDG}_{i}=\beta_{0}+\beta_{1} \mathrm{LEV}_{i}+\beta_{2} \mathrm{GROW}_{i}+\beta_{3} \mathrm{SIZE}_{\mathrm{i}}+\beta_{4} \mathrm{PERF}_{i}+\varepsilon_{i}
$$

where $\mathrm{CDG}_{i}$ represents the Corporate Governance Disclosure index. $\mathrm{LEV}_{\mathrm{i}}$ stands for financial leverage; total remunerated debt divided by total assets at the end of the year (Eng and Mak 2003, Parsa et al. 2007, Oliveira et al. 2013, Scholtz and Smit 2015). GROW $\mathrm{G}_{\mathrm{i}}$ is a price-based proxy for growth opportunities: the sum of the Market Value of Equity plus the Book Value of Debt divided by the Book Value of Assets at the end of the year (Perfect and Wiles 1994, Ghasempour and MdYusof 2014). The variable SIZE $\mathrm{i}_{\mathrm{i}}$ is the logarithm of the firm's total assets, measuring its size (Arcay and Vazquez 2005, Ben-Amar and Zeghal 2011, Mallin and Ow-Yong 2012, Barros et al. 2013, Oliveira et al. 2013).PERF ind $_{i}$ stands for the ration of net income to total equities at the end of the previous year (Eng e Mak 2003, Ben-Amar and Zeghal 2011, Jouirou and Chenguel 2014). Finally, the term $\varepsilon_{i}$ represents the error term.

\section{Data Collection}

\section{$\underline{\text { Construction of the CGD Index }}$}

To analyse the factors that influence the level of GGD in Portugal, we constructed a disclosure index to measure the level of corporate governance information disclosed by Portuguese listed firms. Our data sources include consolidated annual reports and corporate governance reports (for the years 2005 to 2011), obtained from the website of the CMVM.

The primary research instrument used was a pilot test on every company included in the 2011 sample, based on a research protocol developed in the context of corporate governance by recognized institutions and organizations (World Bank, United Nations Conference on Trade and Development - 
UNCTAD, Standard \& Poor's), as well as on OCDE Principles of corporate governance and Portuguese recommendations about corporate governance.

The final disclosure index includes a total of 82 corporate governance attributes grouped into six categories of information: management structure; specialized committees (remuneration and appointment); audit and risk management; ownership structure; compliance and corporate responsibility; and financial transparency.

In order to conduct accurate and reliable content analysis, we identified the meaning of each attribute included in the disclosure index and assessed twice every attribute. Additionally, objective criteria were defined for coding the attributes. All attributes, being disclosed or not, and being applicable or not, were recorded for each firm in each financial year.

For each company, we analysed annual reports and verified if there was any reference to any of the attributes analysed in the present study. If there was at least one reference to an attribute, an indicator taking the value 1 was assigned to the firm for the specific year of the observation. When no reference to the attribute was observed, the indicator takes the value 0 . If the question does not apply to the company, the attribute is classified as "not applicable" (Haniffa and Cooke 2002, Ghazali and Weetman 2006, Lim et al. 2007, Samaha et al. 2012). Given that binary indicators are used to measure the attributes, even if an attribute appeared twice or more in the same report, it was only measured once.

Total disclosure score for each company in each year, is obtained by the following formula:

$\mathrm{DI}=\sum_{i=1}^{n} \frac{I_{i}}{R} \times 100$

where DI is the disclosure index, $\mathrm{n}$ measures the total number of attributes, $\mathrm{I}_{i}$ is an indicator taking the value 1 if the attribute is disclosed and 0 otherwise and $\mathrm{R}$ is the number of all reported attributes, excluding the non-applicable attributes.

Our disclosure index was made using an un-weighted index, that is, a scoring system which assigns a point for each attribute pertaining to any of the categories considered. Disclosure scores for each company were added and not weighted because it is assumed that un-weighted scores produce the same results when the index contains a large number of attributes (Marston and Shrives 1991).

\section{Independent Variables}

The selection of the independent variables was based on the research hypotheses proposed. The relevant data were obtained from companies consolidated annual reports and corporate governance reports. In the absence or impossibility to obtain the required information, data was considered not disclosed and statistically treated as missing. 


\section{Control Variables}

We also introduced control variables that facilitate the isolation of the link leading from the independent to the dependent variables. Controls for type of industry, number of years since the company was admitted to Securities official market and PSI-20 index as well as year dummies are included.

\section{Results}

\section{Descriptive Statistics and Correlation Matrix}

The descriptive statistics for the continuous variables are shown in Panels A and B of Table 1.

Table 1. Descriptive Statistics of the Continuous Variables Panel A: Dependent Variable

\begin{tabular}{lllllllll}
\hline & $\mathbf{2 0 0 5}$ & $\mathbf{2 0 0 6}$ & $\mathbf{2 0 0 7}$ & $\mathbf{2 0 0 8}$ & $\mathbf{2 0 0 9}$ & $\mathbf{2 0 1 0}$ & $\mathbf{2 0 1 1}$ \\
\hline $\begin{array}{l}\text { ÍD_GOVS } \\
\text { oc }\end{array}$ & & & & & & & \\
Mean & $51,3 \%$ & $54,7 \%$ & $59,7 \%$ & $68,1 \%$ & $71,9 \%$ & $76,3 \%$ & $77,7 \%$ \\
Median & $53,8 \%$ & $54,5 \%$ & $59,1 \%$ & $65,9 \%$ & $75,3 \%$ & $77,0 \%$ & $78,5 \%$ \\
Std. & $13,5 \%$ & $13,8 \%$ & $13,7 \%$ & $12,9 \%$ & $12,9 \%$ & $11,3 \%$ & $11,0 \%$ \\
Deviation & $26,8 \%$ & $27,7 \%$ & $27,3 \%$ & $36,1 \%$ & $41,9 \%$ & $48,3 \%$ & $51,5 \%$ \\
Minimum & $2,9,9 \%$ & $76,3 \%$ & $84,6 \%$ & $86,8 \%$ & $89,6 \%$ & $91,1 \%$ & $93,4 \%$ \\
Maximum & $75,9 \%$ & & 37 & 40 & 39 & 39 & 39 \\
\hline & 34 & 35 & 37 & & & &
\end{tabular}

Panel B: Independent Variables

\begin{tabular}{llllll}
\hline Variable & Mean & Median & $\begin{array}{c}\text { St. } \\
\text { Deviation }\end{array}$ & Minimum & $\begin{array}{l}\text { Maximu } \\
\mathbf{m}\end{array}$ \\
\hline LEV & 0,427 & 0,41 & 0,184 & 0,04 & 1,10 \\
GROW (Tobin & 1,203 & 1,09 & 0,449 & 0,51 & 3,66 \\
Q) & & & & & \\
SIZE $\quad(\log$ & 8,832 & 8,84 & 0,707 & 7,38 & 10,36 \\
Assets) & & & & $-12,05$ & 16,36 \\
PERF (ROE) & 0,127 & 0,09 & 1,611 & \\
\hline
\end{tabular}

Note: The values correspond to the average of seven years (2005 to 2011). N=263.

As show in Panel A, the CGD index ranged from $26.8 \%$ to $75.9 \%$, with a mean of $51.3 \%$, and a standard deviation of $13.5 \%$ in 2005 . The mean value of the index has increased over the period analysed, reaching an average of $77.7 \%$ in 2011. The results indicate that there is a wide range of CGD practices applied in Portugal. 
According to Panel B, the average debt levels of Portuguese companies were almost equal to $42.7 \%$ of their assets over the period under analysis. The mean (1.20) and median (1.09) ratios for Tobin Q, being a proxy for growth opportunities was positive, indicating that the Portuguese companies are growing. The distribution of total assets value was normalised, using a log transformation, and its mean level equals 8.83. Finally, the average return on equity ratio, being a proxy for performance, was equal to $12.7 \%$ between 2005 and 2011.

\section{Bivariate Analysis}

The Kolmogorov-Smirnov test shows that the dependent variable does not follow a normal distribution. To solve the normality problem, we transformed the continuous dependent variable to a categorical measure and carried out an ordinal logistic regression. According to the percentiles analysis conducted for the CGD categorical index, the relationship between the latent corporate governance disclosure $\left(\mathrm{y}^{*}\right)$ and the observed index can be observed in the following cut-off points:

$$
\begin{aligned}
& y=1 \text { if } y^{*} \leq 0.60 \\
& y=2 \text { to } 0,601<y * \leq 0.80 \\
& y=3 \text { to } y^{*>} 0,801
\end{aligned}
$$

The bivariate relationships among the continuous variables are presented in table 2. The dependent variable following a non-normal distribution, we proceed to the analysis of the Spearman's correlation coefficients.

\begin{tabular}{|c|c|c|c|c|c|}
\hline & ID_GOVSoc & LEV & GROW & SIZE & PERF \\
\hline ID_GOVSoc & 1 & & & & \\
\hline LEV & $-0,139\left(^{*}\right)$ & 1 & & & \\
\hline GROW & $-0,152$ & 0,116 & 1 & & \\
\hline SIZE & $0,617(* *)$ & 0,042 & 0,061 & 1 & \\
\hline PERF & 0,060 & 0,056 & $0,479(* *)$ & $0,226(* *)$ & 1 \\
\hline
\end{tabular}

Table 2. Bivariate de Correlations

(Spearman correlation coefficients)

* Correlation is significant at the 0,05 level (2-tailed).

** Correlation is significant at the 0,01 level (2-tailed). $\mathrm{N}=263$.

According to the results ${ }^{1}$, the disclosure index is correlated positively with size and negatively with leverage. As expected, there is a significant positive relationship between larger firms, with firm size measured using the log of firms' assets, and performance. Furthermore, a significant positive correlation coefficient between growth opportunities and performance is estimated.

\footnotetext{
${ }^{1}$ No independent variable on our regression had a variance inflation factor exceeding 2.1, suggesting minimal multi-collinearity and stability of parameter estimates.
} 


\section{Multivariate Analysis}

Following Franck and Sundgren (2012), Costa et al. (2013) and Trabelsi et al. (2014), we fit an ordinal logistic regression model to pooled data, controlling for time effects. We also test the significance of each variable's relationship to CGD and eliminate those which do not affect the outcome of interest substantially.

Table 3. Results of the Ordinal Logistic Regression

\begin{tabular}{|c|c|c|c|}
\hline & $\begin{array}{l}\text { Expected } \\
\text { sign }\end{array}$ & ID_GOVSoc & \\
\hline & & Estimates & Sig. \\
\hline LEV & $+/-$ & $-6,105(* *)$ & $(0,000)$ \\
\hline GROW & + & $1,328(*)$ & $(0,034)$ \\
\hline SIZE & + & $4,895(* *)$ & $(0,000)$ \\
\hline PERF & + & $-0,049$ & $(0,830)$ \\
\hline ICB2 & & $-1,844(*)$ & \\
\hline ICB3 & & $-2,850(* *)$ & \\
\hline ICB5 & & $-1,407(*)$ & \\
\hline ANO 3 & + & $2,033(*)$ & \\
\hline ANO 4 & + & $4,804(* *)$ & \\
\hline ANO 5 & + & $6,010(* *)$ & \\
\hline ANO 6 & + & $7,484(* *)$ & \\
\hline ANO 7 & + & $7,507(* *)$ & \\
\hline 2Log Likelihood & & $-220,773$ & \\
\hline$\chi^{2}$ & & 340,334 & \\
\hline$\chi^{2}(p$-value $)$ & & $<0,001$ & \\
\hline Pseudo $R^{2}$ Nagelkerke & & 0,823 & \\
\hline $\begin{array}{l}\text { Overall prediction } \\
\text { accur. }\end{array}$ & & $66,7 \%$ & \\
\hline Observations & & 263 & \\
\hline
\end{tabular}

As shown in table 3, the Pseudo $\mathrm{R}^{2}$ figure indicates that the model explains $82.3 \%$ of the variation in the disclosure index in the present sample. The results indicate that non-financial companies with lower debt ratio disclose more corporate governance information compared to non-financial companies with higher debt ratio. Brammer and Pavelin (2006) and Oliveira et al. (2013) also show a significant, negative relationship between leverage and the level of CGD, which further supports our first hypothesis. The negative sign of the effect could be attributed to the nature of the relationship between banks and Portuguese companies (Oliveira et al., 2013), with banks having full access to information about companies, thus, making less relevant the disclosure of additional information through reports and accounts.

Findings presented in the table 3 also reveal that companies enjoying higher growth opportunities (proxied by Tobin $\mathrm{Q}$ ratio) disclose higher levels 
of CGD ( $\mathrm{p}<0,005)$. Being in agreement with prior work on this topic(Hossain et al., 2005), these results support hypothesis 2 .

Similarly with previous studies (Ben-Amar and Zeghal 2011, Mallin and Ow-Yong 2012) firm size, measured by the log of total assets, is positively related to the level of CGD. This finding validates the third hypothesis while it is also consistent with the argument that larger companies have greater expertise which allows them to prepare and disclose more information about corporate governance practices.

Additionally, the results reveal that firm performance does not influence the level of CGD, consistent with the bivariate analysis and with some prior studies (Barako et al. 2006, Jouirou and Chenguel 2014, Scholtz and Smit 2015). The absence of significant links between performance and CGD persists in the estimation of various regression models with different possible combinations of independent variables, providing no support for the fourth hypotheses 4.

Finally, controlling for exogenous, macro-economic conditions, using year dummies, appears to slightly attenuate the relationships under study. Particularly, an increasing trend is observed, with corporate disclosure index steadily increasing over the period under analysis. Only in 2006, the CGD index did not increase as compared to its 2005 level. This finding is in agreement with the trends observed in the sample, with disclosure level demonstrating modest increase from 2005 to 2006, and more rapid increase from 2007 onwards (see Table 2, Panel A). Further, the level of CGD is observed to be smaller for Basic Materials, Industrial Products and Consumer Services companies operating in the sectors of Basic Materials, Industrial Products and Consumer Services, implying that these companies are potentially more inclined to pursue cost-benefit strategies; ie, achieve the point where the marginal costs of disclosing corporate governance practices exceeds the marginal benefits that may be gained (Mallin and Ow-Yong 2012).

\section{Conclusions}

Using a sample consisting of listed companies operating in Portugal, observed in the period between 2005 and 2011, we investigate the financial determinants of corporate governance disclosure in both stakeholder and agency settings, characterised by information asymmetry. The present study's main findings indicate that CGD followed a positive trend between 2005 and 2011. This trend could be attributed to the positive impact that the Portuguese Corporate Governance Code, improved in 2007 and 2010, had on firms' disclosure levels. Additionally, the estimation of the ordinal logistic model produced some interesting results. First, we find a significant relationship between financial leverage and CGD, suggesting that companies with lower debt levels disclose more information on corporate governance on average; a finding that further validates the stakeholder theory. The finding is also in line with the studies of Eng and Mak (2003) and Barros et al. (2013), who consider 
that high levels of debt act as substitutes to disclosure, through mitigating the problem of free cash flows. However, our findings appear to contradict the expectations and principles of agency theory. Second, firm size appearing to influence CGD levels is consistent with prior work. Additionally, higher growth opportunities are observed to enhance CGD levels. Therefore, our findings are in aggreement to the studies of Hossain et al. (2005) and Alves et al. (2012), which also conclude that companies with higher growth opportunities exhibit greater disclosure levels than companies with lower growth opportunities.Finally, similar to Barako et al. (2006), Jouirou and Chenguel (2014) and Scholtz and Smit (2015), the level of corporate disclosure does not appear to be substantially influenced by firm performance.

This study has both theoretical and practical implications. First, it contributes to existing literature on disclosure of information by focusing on a specific type of information; that related to corporate governance. Moreover, the present study extends prior work by analysing firm dimension as a determinant of information disclosure. Third, the statistical analysis is potentially useful to policy makers in their attempt to formulate corporate governance recommendations and policies. Implications of the present study could also be of great importance to investors and managers, enlightening them regarding the reasons which lead to disclosure initiatives.

Overall, the present study's findings further strengthen the argument that corporate governance plays an important role within companies as it mitigates agency and asymmetric information problems and answers to various stakeholders requests. However, similar to prior work on this topic, the present study faced various, inherent constraints and limitations: first, the limitations imposed by using annual corporate governance reports and accounts; second, the construction of disclosure index inevitably involves some subjectivity, regardless of our attempts to minimise it; third, a non-weighted index is used questioning the external validity of the findings.

\section{References}

Adam T, Goyal V (2008) The Investment Opportunity Set and its proxy Variables. Journal of Financial Research 31(1): 41-63.

Aljifri K, Hussainey K (2007) The Determinants of Forward-Looking Information in Annual Reports of UAE Firms. Managerial Auditing Journal 22(9): 881- 894.

Allegrini M, Greco G (2013) Corporate Boards, Audit Committees and Voluntary Disclosure: Evidence from Italian Listed Companies. Journal of Management \& Governance 17(1): 187-216.

Alves H, Rodrigues AM, Canadas N (2012) Factors Influencing the Different Categories of Voluntary Disclosure in Annual Reports: An Analysis for Iberian Peninsula Listed Companies. Tékhne 10(1): 15-26.

Arcay MRB, Vázquez MF (2005) Corporate Characteristics, Governance Rules and the Extent of Voluntary Disclosure in Spain. Advances in Accounting 21: 299331 . 
Barako DG, Hancock P, IZAN H (2006) Factors Influencing Voluntary Corporate Disclosure by Kenyan Companies. Corporate Governance: An International Review 14(2): 107-125.

Barros CP, Boubaker S, Hamrouni A (2013) Corporate Governance and Voluntary Disclosure in France. The Journal Applied Business Research 29(2): 561-578.

Ben-Amar W, Boujenoui A (2007) Factors Explaining Corporate Governance Disclosure Quality: Canadian evidence. Working Paper: Illinois International Accounting Symposium.

Ben-Amar W, Zeghal D (2011) Board of Directors Independence and Executive Compensation Disclosure Transparency: Canadian Evidence. Journal Applied Accounting Research 12(1): 43-60.

Botosan C, Plumlee M (2002) A Re-Examination of Disclosure Level and the Expected Cost of Equity Capital. Journal of Accounting Research 40: 31-40.

Brammer S, Pavelin S (2006) Voluntary Environmental Disclosure by Large UK Companies. Journal of Business Finance \& Accounting 33(7\&8): 1168-1188.

Bujaki M, Mcconomy BJ (2002) Corporate Governance: Factors Influencing Voluntary Disclosure by Publicly Traded Canadian Firms. Canadian Accounting Perspectives 1(2): 105-139.

Camfferman C (2002) An Analyses of Disclosure in Annual Reports of UK and Dutch Firms. Journal of International Accounting 1: 3-30.

Chavent M, Ding Y, Fu L, Stolowy H, Wang H (2006) Disclosure and Determinants Studies: An extension Using the Divisive Clustering Method (DIV). European Accounting Review 15(2): 181-218.

Cerf AR (1961) Corporate reporting and investment decisions. Berkeley, University of California Press.

Costa GA, Oliveira L, Rodrigues LL, Craig R (2013) Factors Associated with the Publication of a CEO Letter. Corporate Communications: An International Journal 18(4): 432-450.

Craven M, Claire L (1999) Financial Reporting on the Internet by Leading UK firms. European Accounting Review 8(2): 321-333.

Darrough MN, Stoughton NM (1990) Financial Disclosure Policy in an Entry Game. Journal of Accounting Economics 12(1-3): 219-243.

Diamond D, Verrecchia R (1991) Disclosure, Liquidity, and the Cost of Capital. The Journal of Finance 66: 1325-1355.

Eng LL, Mak YT (2003) Corporate Governance and Voluntary Disclosure. Journal of Accounting and Public Policy 22(4): 325-345.

Franck P, Sundgren S (2012) Determinants of internal governance quality: evidence from Sweden. Managerial Auditing Journal 27(7): 639-665.

Gaver JJ, Gaver KJ (1993) Additional Evidence on the Association between the Investment Opportunity Sand and Corporate Financing, Dividend and Compensation Policies. Journal of Accounting Economics 16: 125-160.

Ghasempour A, MdYusof MA (2014) The Effect of Fundamental Determinants on Voluntary Disclosure of Financial and Nonfinancial Information: The Case of Tehran Stock Exchange. Journal of Accounting \& Marketing 3(2): 1-6.

Ghazali N, Weetman P (2006) Perpetuating Traditional Influences: Voluntary Disclosure in Malaysia Following the Economic Crisis. Journal of International Accounting Auditing \& Taxation 15(2): 226-248.

Gibbins M, Richardson A, Waterhouse J (1990) The Management of Corporate Financial Disclosures: Opportunism, Ritualism, Policies, and Processes. Journal of Accounting Research 28: 121-143. 
Gul FA, Leung S (2004) Board Leadership, Outside Directors Expertise and Voluntary Corporate Disclosures. Journal of Accounting and Public Policy 23(5): 351-379.

Haniffa RM, Cooke TE (2002) Culture, Corporate Governance and Disclosure in Malaysian Corporations. Abacus 38(3): 317-349.

Healy P, Palepu K (2001) Information Asymmetry, Corporate Disclosure, and the Capital Markets: A Review of the Empirical Disclosure Literature. Journal of Accounting Economics 31: 405-440.

Healy P, Hutton AP, Palepu KG (1999) Stock Performance and Intermediation Changes Surrounding Sustained Increases in Disclosure. Contemporary Accounting Research 16(3): 485-520.

Ho PL, Tower G, Barako D (2008) Improving Governance Leads to Improved Communication. Corporate Ownership Control 5(4): 26-33.

Hossain M, Ahmed K, Godfrey JM (2005) Investment Opportunity Set and Voluntary Disclosure of Prospective Information: A Simultaneous Equations Approach. Journal of Business Finance Accounting 32(5-6): 877-907.

Huafang X, Jianguo Y (2007) Ownership Structure, Board Compensation and Corporate Voluntary Disclosure: Evidence from Listed Firms in China. Managerial Auditing Journal 22: 604-619.

Hutchinson M, Gul F (2004) Investment Opportunity Set, Corporate Governance Practices and Firm Performance. Journal Corporate Finance 10(4): 595-614.

James HL (2011) Is Small and Independent Board a Better Board? An Example of High-Tech Industries. Paper presented at the 2012 MFA Annual Meeting, New Orleans, LA, USA.

Jensen MC, Meckling WH (1976) Theory of the Firm: Managerial Behaviour, Agency Costs and Ownership Structure. Journal Financial Economics 3: 305-360.

Juhmani OI (2013) Ownership Structure and Corporate Voluntary Disclosure: Evidence from Bahrain. International Journal Accounting Financial Reporting 3(2): 133-148.

Jouirou M, Chenguel MB (2014) The Determinants of Voluntary Disclosure in Tunisia: A Study of the Firms Listed in the Tunisian Stock Exchange. Journal Business Management Research 4: 86-97.

Kateb I (2012) An Analysis of the Determinants of Voluntary Structural Capital Disclosure by Listed French Firms. International Journal Business Management 7(11): 95-110.

Kim O, Verrecchia R (1994) Market Liquidity and Volume around Earnings Announcements. Journal Accounting Economics 17: 41-68.

Lang M, Lundholm R (2000) Voluntary Disclosure and Equity Offerings: Reducing Information Asymmetry or Hyping the Stock? Contemporary Accounting Research 17(4): 623-642.

Lang L, Ofek E, Stulz R (1994) Tobin's Q, Corporate Diversification and Firm Performance. Journal of political Economics 102: 1248-1280.

Lawrence J, Stapledon GP (1999) Is Board Composition Important? A study of listed Australian Companies. Working Paper University of Melbourne, Australia.

Leftwich R, Watts R, and Zimmerman JL (1981) Voluntary Corporate Disclosure: The Case of Interim Reporting. Journal Accounting Research 19(Suppl): 50-77.

Lev B (1992) Information Disclosure Strategy. California Management Review 34(4): 9-32.

Lim S, Matolcsy Z, Chow D (2007) The Association between Board Composition and Different Types of Voluntary Disclosure. European Accounting Review 16(3): $555-583$. 
Litan R, Wallison P (2000) The GAAP Gap: Corporate Disclosure in the Internet Age. Washington, DC: AEI-Brookings Joint Center for Regulatory Studies.

Lopes P, Rodrigues L (2007) Accounting for Financial Instruments: an Analysis of the Determinants of Disclosure in the Portuguese Stock Exchange. International Journal Accounting 42(1): 25-56.

Mallin C, Ow-Yong K (2012) Factors Influencing Corporate Governance Disclosures: Evidence from Alternative Investment Market (AIM) Companies in the UK. The European Journal of Finance 18(6): 515-533.

Marston C, Shrives P (1991) The Use of Disclosure Indices in Accounting Research: A Review Article. British Accounting Review 23(3): 195-210.

Marston C, Polei A (2004) Corporate Reporting on the Internet by German Companies. International Journal Accounting Information Systems 5: 285-311.

Oliveira L, Rodrigues LL, Craig R (2013) Stakeholder Theory and the Voluntary Disclosure of Intellectual Capital Information. Caspian Journal of Applied Sciences Research 2(3): 75-93.

Parsa S, Chong G, Isimoya E (2007) Disclosure of Governance Information by Small and Medium-Sized Firms. Corporate Governance: The International Journal Business in Society 7(5): 635-648.

Perfect SB, Wiles KW (1994) Alternative Constructions of Tobin's q: An Empirical Comparison. Journal of Empirical Finance 1: 313-341.

Peterson M, Rajan R (1994) The Benefits of Lending Relationship: Evidence from Small Business Data. The Journal of Finance 49(1): 3-37.

Raffournier B (1995) The Determinants of Voluntary Financial Disclosure by Swiss Listed Firms. European Accounting Review 4(2): 261-280.

Samaha K, Dahawy K, Hussainey K, Stapleton P (2012) The Extent of Corporate Governance Disclosure and its Determinants in a Developing Market: The Case of Egypt. Advances in Accounting 28: 168-178.

Sengupta, P (1998) Corporate disclosure quality and the cost of debt. Accounting review, 73(4): 459-474.

Scholtz H, Smit A (2015) Factors Influencing Corporate Governance Disclosure of Firms Listed on the Alternative Exchange (ALTX) in South Africa. South African Journal of Accounting Research 29(1): 29-50.

Schiantarelli F (2005) Financial Constraints and Investment: A Critical Review of Methodological Issues and International Evidence. MA: Federal Reserve Bank of Boston.

Silva F, Carreira C (2010) Financial Constraints: Are there Differences between Manufacturing and Services. Estudos do GEMF 16/2010 Coimbra: GEMF, Universidade de Coimbra.

Smith C, Watts R (1992) The Investment Opportunity Sand and Corporate Financing, Dividend and Compensation Policies. Journal of Financial Economics 32: 263292.

Trabelsi S, Debreceny R, Lymer A (2014) An Empirical Examination of Corporate Websites as a Voluntary Disclosure Medium. International Journal of Applied Decision Sciences 7(1): 1-32.

Verrecchia RE (1983) Discretionary Disclosure. Journal of Accounting Economics 5: 179-194.

Yermack D (1996) Higher Market Valuation of Firms with a Small Board of Directors. Journal of Financial Economics 40(2): 185-211. 
